\title{
Serogrouping of Thermophilic Campylobacter from Gulls by Slide Agglutination Based on Heat-labile Antigenic Factors
}

Choji KANEUCHI, Miki ASHIHARA, Kahiko SAITO ${ }^{1)}$, and Takeshi ITOH $^{1)}$

Second Department of Veterinary Public Health, Azabu University, Sagamihara, Kanagawa 229, and ${ }^{1)}$ Department of Microbiology, Tokyo Metropolitan Research Laboratory of Public Health, Hyakunin-cho, Shinjuku-ku, Tokyo 160, Japan

(Received 29 March 1988/Accepted 6 November 1988)

Jpn. J. Vet. Sci. 51(2): 431-433, 1989

KEY WORDS: Campylobacter, gull, serogroup.

Thermophilic Campylobacter has been recognized as one of the most common causes of bacterial enteritis in humans $[1,15]$, and is carried by a wide range of wild and domestic animals. The role of each animal species to human infection is not well understood. This epidemiological problem can be further investigated by the introduction of effective methods for differentiation of isolates, based on biochemical and serological criteria.

Wild seabirds like gulls are known to harbor characteristically Campylobacter laridis as well as Campylobacter jejuni and Campylobacter coli at relatively high frequency $[3,8,10]$. We [7] previously reported that gulls in Japan also harbor the 3 species of Campylobacter at the rates comparable to those in other countries [3]. Rosef $e t$ al. [13] reported that wild birds including gulls carry Campylobacter serotypes that also occur in human patients suffering from Campylobacter enteritis. No investigation has been made of the relatedness between the seabird campylobacters and human enteritis in Japan.

The purpose of the present study is to serogroup the thermophilic Campylobacter from gulls by slide agglutination and to examine its relationship to human gastroenteritis.

A total of 76 gull campylobacters was subjected to serological grouping. They consisted of 37 C. jejuni, 19 C. coli, and 20 C. laridis strains previously isolated from black-headed gulls on the coast of Tokyo Bay and black-tailed gulls at the estuary of the Sagami River [7]. Strains were incubated at $37^{\circ} \mathrm{C}$ for $24 \mathrm{hr}$ with shaking in brain heart infusion (Difco) in test tubes filled with gas mixture $\left(5 \% \mathrm{O}_{2}: 10 \% \mathrm{CO}_{2}: 85 \% \mathrm{~N}_{2}\right)$ and sealed by rubber stoppers. For $C$. laridis strains, calf serum was added to the broth at a final concentration of $0.5 \%$ as supplement. The broth culture $(0.3 \mathrm{ml})$ was spread onto nutrient agar (Nissui) and incubated in a jar filled with the gas mixture at $37^{\circ} \mathrm{C}$ for $48 \mathrm{hr}$. Cells were suspended in physiological saline containing $0.3 \%$ formalin and used as antigens.

Serogrouping was accomplished by using Lior method (60 antisera). The Lior antisera were prepared in rabbits according to the scheme by Lior et al. [9] against Lior antigens, LIO1 to LIO66 (missing antigens; LIO3, 21, 37, 43, 58, and 65). Some Lior antisera were absorbed with heterologous cross reactive antigens. The Lior method has been approved as an international Campylobacter serogrouping method by the International Committee of Campylobacter Serogrouping in 1985 [14]. In this study, however, TCK (32 antisera) and CCK (20 antisera) methods were also used additionally, which were developed by Itoh et al. [6] by employing mostly human $C$. jejuni and $C$. coli strains, respectively, as antigens.

As shown in Table 1, among 76 strains from gulls, 45 strains $(59.2 \%)$ ) could be serogrouped by Lior method; namely, 26 (70.3\%) of 37 C. jejuni strains, $7(36.8 \%)$ of 19 C. coli strains, and 12 $(60.0 \%)$ of $20 \mathrm{C}$. laridis strains. Of these strains, 32 strains reacted in single antisera, while 10 strains reacted in pairs of antisera and 3 strains agglutinated in 3 different antisera. The remaining 31 strains were non-agglutinable. Twentyseven serogroups were distinguished in all. Serogroup LIO12 of $C$. jejuni was encountered at relatively high frequency and commonly found in the 2 flocks of gulls.

On the other hand, 24 strains $(31.6 \%)$ of the gull strains were serogrouped by both TCK and CCK methods; that is, $16(43.2 \%)$ of $C$. jejuni strains, $5(26.3 \%)$ of $C$. coli strains, and 4 $(20.0 \%)$ of $C$. laridis strains. Among these strains, 21 strains reacted in single antisera, while 3 strains reacted in pairs of antisera. The remaining 52 strains were non-agglutinable. Sixteen serogroups were distinguished by both the TCK and CCK methods.

Campylobacter serogrouping systems based on 
Table 1. Serogroups of thermophilic Campylobacter from gulls

\begin{tabular}{|c|c|c|c|c|c|}
\hline \multicolumn{2}{|c|}{ C. jejuni } & \multicolumn{2}{|c|}{ C. coli } & \multicolumn{2}{|c|}{ C. laridis } \\
\hline $\begin{array}{l}\text { Serogroup } \\
\text { Lior }\end{array}$ & $\begin{array}{l}\text { No. of } \\
\text { strain }\end{array}$ & $\begin{array}{l}\text { Serogroup } \\
\quad \text { Lior }\end{array}$ & $\begin{array}{c}\text { No. of } \\
\text { strain }\end{array}$ & $\begin{array}{l}\text { Serogroup } \\
\quad \text { Lior }\end{array}$ & $\begin{array}{l}\text { No. of } \\
\text { strain }\end{array}$ \\
\hline $11(4)^{a)}$ & 2 & 40 & 1 & 17 & 1 \\
\hline 12 & 7 & $57(9)$ & 2 & 42 & 2 \\
\hline $13(1)$ & 3 & 59 & 1 & $55(\mathrm{CCK} 8)^{\mathrm{b})}$ & 1 \\
\hline $16(32)$ & $2^{c)}$ & 60 & 1 & 56 & 4 \\
\hline 42 & 1 & $14,17^{\mathrm{d})}(1)$ & 1 & 20,42 & 1 \\
\hline 46 & 1 & 35,42 & 1 & $32,39(\mathrm{CCK} 5)$ & 1 \\
\hline 49 & 2 & $\mathrm{UG}^{\mathrm{e})}(1)$ & 1 & $42,56(\mathrm{CCK} 5)$ & 1 \\
\hline $57(9)$ & 1 & UG (19) & 1 & $12,16,42(3)$ & 1 \\
\hline 12,17 & 1 & $\mathrm{UG}$ & 10 & UG & 8 \\
\hline 12,61 & 1 & & & & \\
\hline $23,42(19)$ & 1 & & & & \\
\hline $49,63(17)$ & 2 & & & & \\
\hline $10,11,14(4,6)$ & 2 & & & & \\
\hline $\mathrm{UG}(20)$ & 1 & & & & \\
\hline UG (25) & 1 & & & & \\
\hline $\mathrm{UG}(6,10)$ & 1 & & & & \\
\hline $\mathrm{UG}$ & 8 & & & & \\
\hline Total & 37 & & 19 & & 20 \\
\hline
\end{tabular}

a) Number in parentheses indicates TCK serogroups.

b) Number in parentheses indicates CCK serogroups.

c) One strain not agglutinable in the TCK antiserum.

d) The strain agglutinated in a pair of Lior antisera.

e) Ungroupable.

heat-labile antigenic factors have been investigated so far by Lior et al. [9], Itoh et al. [6], and Rogol et al. [12]. It is considered that the antigenic factors in these systems consist mainly of flagella components but some somatic components are also involved. Corresponding serogroups among the Lior, TCK, CCK, and Rogol serogroups were reported by Itoh et al. [5]. Some of the corresponding serogroups (LIO11, 13, and 55 to TCK 4 , TCK 1 , and CCK 8 , respectively) were also observed in the present study.

Serogroups LIO11 (TCK4) and LIO13 (TCK1) of C. jejuni, which have been found predominantly among humans $[9,14]$, were also identified among the gulls, although at the low rates. These serogroups have been detected also from chickens, swine, wild fowls, and others [9, 14]. They, therefore, seem to distribute in a wide range of domestic and wild animals.

Percentages of serogroupable gull campylobacters were $59.2 \%$ ( 45 strains) by Lior method and
$31.6 \%$ (25 strains) by TCK and CCK methods, and as for C. jejuni strains, 70.3 and $43.2 \%$, respectively. These percentages are fairly lower than those of more than $90 \%$ for human, animal, and environmental C. jejuni strains [11] and about $85 \%$ for human and chicken $C$. jejuni strains [9] by Lior method. Fukuyama et al. [4] also reported a low percentage $(37 \%)$ of serogroupable wild bird campylobacters by the TCK and CCK methods, although much higher percentage (approximately $80 \%$ ) of human enteritis strains were serogrouped by the same methods. These relatively low percentages of serogroupable wild bird campylobacters by the TCK and CCK methods may be partly due to the fact that the methods were developed by using mostly human strains as antigens. From these results, it seems difficult to presume a close relation between gulls and the human campylobacter enteritis, although the numbers of gulls, areas, and periods examined were limited. However, as 
several sporadic cases [16] and a water-borne outbreak [2] of human gastroenteritis associated with $C$. laridis, which is principally found in seagulls [3, 7], have recently been reported, further prospective and extensive epidemiological investigation must be made to clarify the significance of seabirds as a potential source of human enteritis.

ACKNowledgements. We express our thanks to Dr. H. Lior, Laboratory Centre for Disease Control, Ottawa, Canada, for supplying strains.

\section{REFERENCES}

1. Blaser, M. J., Taylor, D. N., and Feldman, R. A. 1983. Epidem. Rev. 5: 157-176.

2. Broczyk, A., Thompson, S., Smith, D., and Lior, H. 1987. Lancet i: 164-165.

3. Fricker, C. R., Girdwood, R. W. A., and Munro, D. 1983. J. Hyg., Camb. 91: 445-450.

4. Fukuyama, M., Kamimura, T., Itoh, T., Saito, K., Takahashi, M., Sakai, S., Murata, M., Kohzaki, K., Hara, M., Shimizu, T., and Tabuchi, K. 1986. Jpn. J. Vet. Sci. 48: 487-493.

5. Itoh, T., Saito, K., Shingaki, M., and Takahashi, M. 1988. Clin. Microbiol. 15: 88-96.

6. Itoh, T., Saito, K., Yanagawa, Y., Sakai, S., and
Ohashi, M. 1982. pp. 106-110. In: Campylobacter: Epidemiology, Pathogenesis and Biochemistry (Newell, D. G. ed.), MTP press, Lancaster.

7. Kaneuchi, C., Imaizumi, T., Sugiyama, Y., Kosako, Y., Seki, M., Itoh, T., and Ogata, M. 1987. Jpn. J. Vet. Sci. 49: 787-794.

8. Kapperud, G. and Rosef, O. 1983. Appl. Environ. Microbiol. 45: 375-380.

9. Lior, H., Woodward, D. L., Edgar, J. A., Laroche, L. J., and Gill, P. 1982. J. Clin. Microbiol. 15: 761-768.

10. Luechtefeld, N. A. W., Blaser, M. J., Reller, L. B., and Wang, W. L. 1980. J. Clin. Microbiol. 12: 406-408.

11. Patton, C. M., Barrett, T. J., and Morris, G. K. 1985. J. Clin. Microbiol. 22: 558-565.

12. Rogol, M., Sechter, I., Braunstein, I., and Gerichter, C. B. 1983. J. Clin. Microbiol. 18: 283-286.

13. Rosef, O., Kapperud, G., Lauwers, S., and Gondrosen, B. 1985. Appl. Environ. Microbiol. 49: $1507-1510$.

14. Saito, K., Takano, I., Takahashi, M., Yanagawa, Y., Itoh, T., Kudo, Y., and Ohashi, M. 1987. Jpn. J. Bacteriol. 42: 499-511 (in Japanese).

15. Skirrow, M. B. 1987. Epidem. Inf. 99: 647-657.

16. Tauxe, R. V., Patton, C. M., Edmonds, P., Barrett, T. J., Brenner, D. J., and Blake, P. A. 1985. J. Clin. Microbiol. 21: 222-225.

要 約

カモメ由来 thermophilic Campylobacterの易熱性抗原による血清群別（短報）：金内長司・足原美樹・斉藤香 彦 $^{1)}$. 伊藤 武 ${ }^{1)}$ (麻布大学獣医公衆衛生学第二講座, ${ }^{1)}$ 東京都立衛生研究所微生物部)一一七メ由来 C. jejuni, C. coli および C. laridis を含む76株のうち45株 (59.2\%) がLior 法で34群に群別され，そのうちC. jejuni の LIO12が比較的高い頻度 $(9.2 \%)$ で検出された。 カモメとヒト腸炎の関連性は低いと考えられた。 